\title{
Microplastics Pollution in Chile: Current Situation and Future Prospects
}

\author{
Esteban Paredes-Osses ${ }^{1,2}$, Karla Pozo ${ }^{3,4}$, Andrés Opazo-Capurro ${ }^{5,6}$, Paulina Bahamonde ${ }^{7 *}$ \\ and Jaime R. Cabrera-Pardo ${ }^{8,9 *}$
}

\begin{abstract}
${ }^{1}$ Sección Microbiología de Alimentos, Departamento de Salud Ambiental, Instituto de Salud Pública de, Santiago, Chile, ${ }^{2}$ Facultad de Medicina Veterinaria y Agronomía, Universidad de Las Américas, Santiago, Chile, ${ }^{3}$ Recetox (Research Center for Toxic Compounds in the Environment), Faculty of Science, Masaryk University, Brno, Czechia, ${ }^{4}$ Faculty of Engineering and Technology, San Sebastián University, Concepción, Chile, ${ }^{5}$ Laboratorio de Investigación en Agentes Antibacterianos (LIAA), Facultad de Ciencias Biológicas, Universidad de Concepción, Concepción, Chile, ${ }^{6}$ Millennium Nucleus for Collaborative Research on Bacterial Resistance (MICROB-R), Santiago, Chile, ${ }^{7}$ Laboratory of Aquatic Environmental Research, Centro de Estudios Avanzados - HUB Ambiental UPLA, Universidad de Playa Ancha, Valparaíso, Chile, ${ }^{8}$ Department of Biochemistry, University of Utah, Salt Lake City, UT, United States, ${ }^{9}$ Laboratorio de Química Aplicada y Sustentable, Departamento de Química, Facultad de Ciencias, Universidad del Bío-Bío, Concepción, Chile
\end{abstract}

\section{OPEN ACCESS}

Edited by:

Nsikak U. Benson,

Covenant University, Nigeria

Reviewed by:

Segun Ayejuyo,

University of Lagos, Nigeria

*Correspondence:

Paulina Bahamonde

paulina.bahamonde@upla.cl

Jaime R. Cabrera-Pardo

j.cabrera@utah.edu

Specialty section:

This article was submitted to

Toxicology, Pollution and the

Environment

a section of the journal

Frontiers in Environmental Science

Received: 18 October 2021

Accepted: 08 November 2021

Published: 25 November 2021

Citation:

Paredes-Osses E, Pozo K,

Opazo-Capurro A, Bahamonde $P$ and

Cabrera-Pardo JR (2021)

Microplastics Pollution in Chile: Current

Situation and Future Prospects.

Front. Environ. Sci. 9:796989.

doi: $10.3389 /$ fenvs.2021.796989
Millions of tons of plastics enter wild habitats, especially the oceans, every year. Despite extensive efforts, this amount is predicted to increase over in the near future, leading to a catastrophic damage to the environment. Small plastic fragments, including microplastics, are currently widely distributed in different environments and contribute significantly to pollution of the oceans. This problem is particularly poignant in Chile, a country with more than $4,000 \mathrm{~km}$ of coastline along the Pacific Ocean home to diverse environments, industrial activities and unique biodiversity. In this review, we compile information regarding microplastics pollution in Chilean environments in terms of transport, distribution and bioaccumulation along the country, societal actions such as environmental policies and education to tackle the plastic problem, and the Trojan effect associated with it. Finally, we identify critical scientific gaps, such as the transport of harmful chemicals and microbial communities associated, and define potential future research directions.

Keywords: microplastics, chemical pollution, microbial communities, trojan effect, Chile

\section{INTRODUCTION}

The global production of plastics has dramatically increased over the last decade, reaching over 380 million tons per year (Geyer et al., 2017). Every year, millions of tons of plastics enter the oceans. Despite extensive efforts invested in recycling plastics, these figures are predicted to increase over the next decade, leading to severe and irreversible damage to the environment (Law and Thompson, 2014; Bornscheuer, 2016).

In terms of plastic fragments, Hartmann et al. (2019) defined the following sizes: macroplastics (greater than $1 \mathrm{~cm}$ ), mesoplastics (between 1 and $10 \mathrm{~mm}$ ), microplastics (between 1 and 1,000 $\mu \mathrm{m}$ ) and nanoplastics (between 1 and 1,000 nm). However, the larger scientific community has continued to conceptualize microplastics as those that are less than $5 \mathrm{~mm}$ in length. Microplastics are classified as primary when they are originally designed to such a small size, such as for use in facial cleansers, cosmetic preparations, air blast cleaning media, etc. (De Falco et al., 2020). Secondary microplastics 
are derived from larger plastic items as a result of the weathering process (Gouin et al., 2011). Boucher and Friot (2017), concluded that, globally, between 0,8 and 2,5 million tons of microplastics are released into the ocean each year. Therefore, there is a concern regarding their ubiquitous presence and accumulation through the food webs.

Microplastics have been detected in seafood (Andrade and Ovando, 2017), honey and alcohol (Cox et al., 2019), plastic teabags (Hernandez et al., 2019), beer (Liebezeit and Liebezeit, 2014), milk (Kutralam-Muniasamy et al., 2020), different types of salts (Karami et al., 2017), and food and water on plastic containers (Fadare et al., 2020). In fact, Cox et al. (2019), estimate that a person could ingest annually between 39,000 and 52,000 microplastic particles through food. These numbers increase to 74,000 and 121,000 when breathing is included. Several efforts have been devoted to evaluate microplastics in terrestrial and marine fauna UNEP (2016). However, research is still needed to assess the effect of microplastics on human and environmental health (Wang et al., 2019). The latest report from the World Health Organization (WHO, 2017) makes an important call to study the physical hazards, chemical agents and microbial pathogens associated with microplastics in water for human consumption, in order to better understand their health risks.

Globally, 44 countries are actively conducting research on the impact of microplastic pollution (Ajith et al., 2020). This represents only $23 \%$ of the total number of countries in the world, and most of these are from Europe and Asia. In Latin America, research in this area is just starting with emerging efforts in Chile, Argentina, Brazil, Colombia and Mexico (Kutralam-Muniasamy et al., 2020). Chile is a country of multiple environments. Continental Chile has a long latitudinal gradient $(>4,000 \mathrm{~km})$ between $17^{\circ} 30 \mathrm{~S}$ and $56^{\circ} 30 \mathrm{~S}$. Briefly, Valdés-Pineda et al. (2014) described a wide range of landscapes, with arid and semi-arid climates in northern regions, temperate climates in central Chile, humid climates in southern regions, and tundra and polar climates in the Andes Mountains. Moreover, Chile also has several oceanic currents that shape the landscape. Part of the West Drift current meets the continent (40 a $45^{\circ} \mathrm{S}$ ) to form the Humboldt current system (HCS) that flows predominantly northward and the Cape Horn current that flows southward. Thus, taking into consideration the biogeographic landscape that defines the Chilean territory, it is paramount to engage the scientific and governmental communities in order to investigate the scope of microplastic pollution in Chilean environments. Increasing scientific knowledge, developing research capacity, and transferring marine technology, will be compulsory for the country.

The plastic problem has been a matter of concern for the Chilean government and some efforts towards mitigation have been put in place. The degradation of plastics bags in the environment is a major contributor to microplastic pollution (Tziourrou et al., 2021). In November 2018, Chile was the first country in Latin America to eliminate single-use plastic bags from commerce, and now single-use plastic containers will be prohibited as well, as a national strategy to reduce the impact of plastic on the environment. Currently, there is a national strategy for marine and microplastic waste management proposed by the Ministry of the Chilean Environment, maritime authorities (Directemar) and Circular economy division (MMA, 2021-https://mma.gob.cl/publicacionesdestacadas/). Despite these endeavors, the scientific literature about microplastics in Chile remains limited. The goal of this review is to synthesize the existing information regarding microplastics pollution in Chilean environments, identify critical scientific gaps and suggest future research directions.

\section{Distribution and Bio-Occurrence of Microplastics in the Chilean Environment}

To the best of our knowledge, all the scientific information regarding plastic fragments, including microplastics in Chile, is summarized in Figure 1. In 2009, Bravo et al. (2009) published the first report of marine debris (Figure 1A) from 43 beaches along the country, reporting the region of Antofagasta and Tarapacá (in the extreme north) and Aysén and Magallanes (in the far south) as the most polluted regions. Such results might be due to the oceanic currents' role on the plastic debris distribution. Later studies have also reported marine debris in Easter Island South Pacific Subtropical Gyre (Hidalgo-Ruz and Thiel, 2013), and the Chilean Northern Patagonia (PerezVenegas et al., 2017).

Beyond this, information on microplastics in Chile is scarce. There are only two reports on microplastic pollution at marine sites and one from soil (Figure 1B). Among marine sites, the highest densities of microplastics $\left(>20,000\right.$ items $\left.\mathrm{km}^{-2}\right)$ were found near Easter Island and Sala y Gomez Islands, very likely by the above mentioned South Pacific Subtropical Gyre. In addition, some sites close to Juan Fernandez Archipelago also had densities up to 20,000 items $\mathrm{km}^{-2}$. The continental coast did not have as high densities as the open ocean Island (Thiel et al., 2018; Pozo et al., 2020). In Castillo et al. (2020) reported microplastics in the water column with densities between 0.1 and 7 particles $/ \mathrm{m}^{3}$. However, fibers were ignored for these analyses because of the potential cross-contamination during sampling (i.e. from nets and clothes). Finally, analysis of soil from 240 sites within the most urbanized Chilean area, the Metropolitana Region (over 7 million people in $15.403,20 \mathrm{~km}^{2}$ ) showed that microplastics were present in croplands and pastures, but concluded that microplastic pollution is not ubiquitous, with microplastics found more often in managed lands and less likely to reach natural, unmanaged soils (Corradini et al., 2021).

Early work on the presence of microplastics in marine organisms in Chile by Andrade and Ovando (2017) reported microplastics in stomach contents of southern king crabs (Lithodes santolla), from Nassau bay - Cape horn, Chile (Figure 1B). This remote ecosystem is known to be one of the most pristine areas in the world with a very low human intervention. The observation that $L$. santolla is ingesting microplastic fibers shows that plastic pollution is even invading the Magellanic marine waters. L. santolla is an important food source for humans and more studies are needed in order to assess the potential human health risk caused by the consumption of microplasticcontaining crabs. 


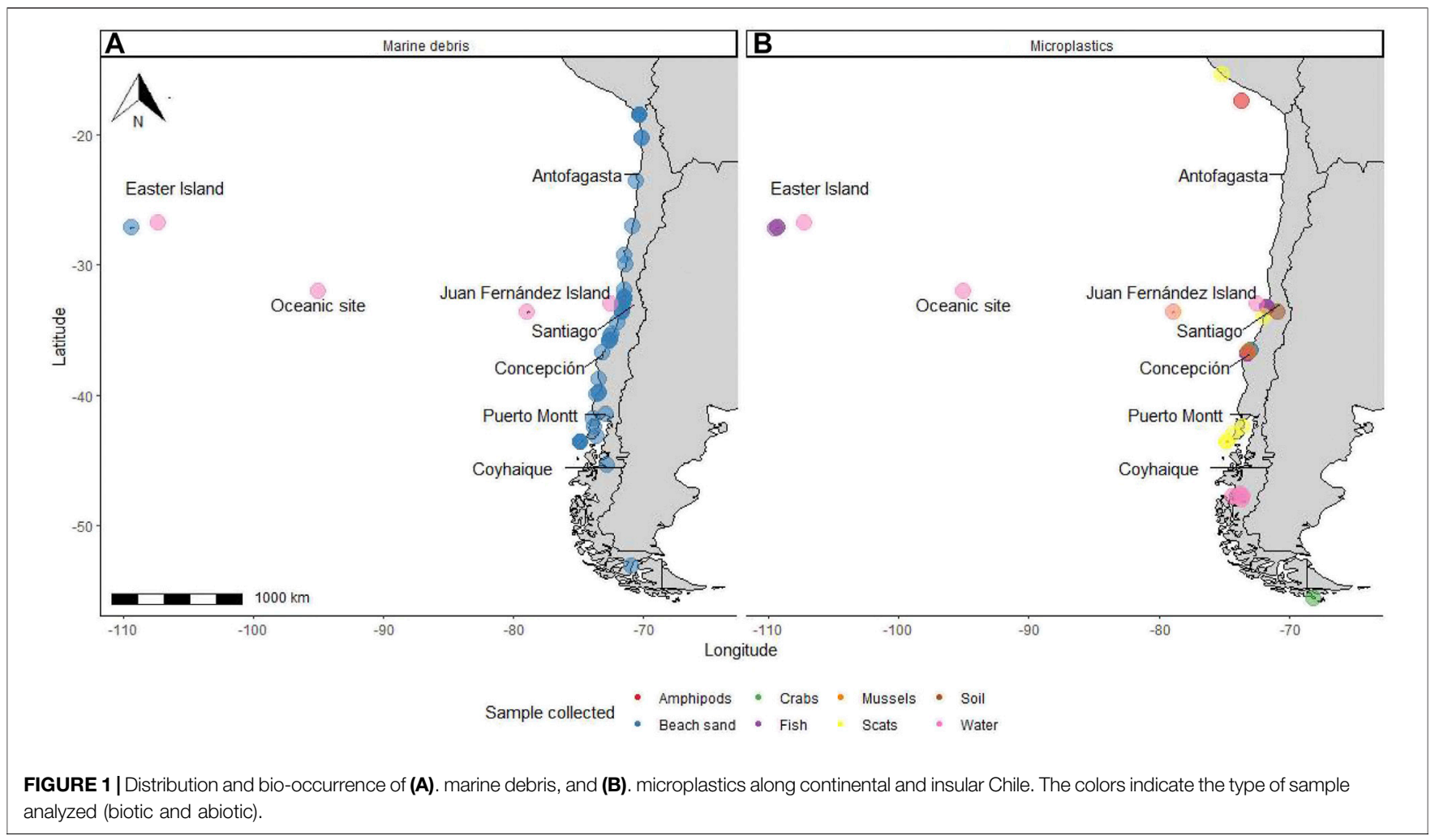

More generally, the trophic transfer of microplastic is not totally understood. Planktivorous fish Cheilopogon rapanouiensis (Exocoetidae) ingest microplastic, however microplastics were not observed in the top predator, the tuna Thunnus albacares, implying no accumulation of microplastics in tuna. Yet, mesoplastics $(15.2-26.3 \mathrm{~mm})$ were found in tuna, indicating that larger plastic objects may accumulate in the gut of $T$. albacares (Chagnon et al., 2018). In addition, Ory et al. (2017) showed that the fish amberstripe scad (Decapterus muroadsi) from Rapa Nui Easter Island, Chile (Figure 1B) ingests microplastic, with strong selectivity to blue PE microplastics resembling their natural prey, which are blue copecods (Pontella sinica and Sapphirina sp.).

Mizraji et al. (2017) studied the occurrence of microplastics in intertidal fish with different feeding types. Juvenile fish were captured in Las Cruces, central Chile (Figure 1B) including an omnivore (Girella laevifrons), an herbivore (Scarthychthys viridis) and several carnivorous species (Graus nigra, Helcogramoides chilensis and Auchenionchus microcirrhis). The authors reported that omnivorous fish showed the highest occurrence of microplastics in their digestive tracts, with microfibers the most abundant, making up to $99 \%$. This observation may be explained by the omnivores' wider range of diet source, increasing the chances to ingest microplastics (Fariña et al., 2000).

Finally, Pozo et al. (2019) assessed the occurrence of microplastics in gastrointestinal content of fish of commercial relevance: the coastal species Eleginops maclovinus, Aplodactylus punctatus and Basilichthys australis; and the oceanic fishes Trachurus murphyi, Strangomera bentincki and Merluccius gayi from the Bio region in central Chile (Figure 1B). The results showed a difference in microfiber distribution between coastal and ocean species. In oceanic fish, a lower microfiber content was found, with B. australis, captured near the mouth of the Biobío River, presenting the highest detection frequency of microplastics (70\%). These results suggest that marine species living in coastal environments, which are exposed to anthropogenic activities, have a higher propensity to ingest microplastics.

In Chile, studies investigating the presence of microplastics in marine mammals are even more scarce (Figure 1B). PerezVenegas et al. (2018) reported an abundance of microfibers (2.7-13.35 particles/g) in scats from $67 \%$ of adult female South American fur seals (Arctocephalus australis) sampled on Guafo Island, Chilean Patagonia. Recently, Perez-Venegas et al. (2020) expanded this investigation and explored the occurrence of microplastic ingestion by Otariids along the Chilean and Peruvian coasts. The most common type of plastic was microfiber, suggesting that fibers are more available than fragments. Scats samples from Juan Fernández Archipelago displayed higher microplastic concentrations than samples from continental rookeries. This study represents a useful, non-invasive strategy to track plastic pollution in marine mammals' diet and could be employed as a tool for future monitoring plans. 


\section{Society and Government Actions in Chile to Control Plastic Pollution}

In 2015, Chile assumed the international commitment in Sustainable Development Goals (SDGs, https:/www.un.org/ sustainabledevelopment/). The SDGs are actions by all participating countries to enhance prosperity and to protect the planet, and include initiatives for marine conservation and ocean protection that were partially developed in Chile. The Chilean Government agreed to develop a National Strategy on marine litter together with an Action Plan, for the period 2021-2030. During 2021, a public consultation for a "Proposal for a National Strategy on Marine Waste and Microplastics" is being developed (https://consultasciudadanas.mma.gob.cl/ portal/consulta/103). An important goal of this initiative is to minimize the risks and impacts marine waste and microplastics cause to the aquatic environment as well as to the economic activities associated with it. Towards this goal, Chile's efforts will focus on approaches aiming: 1) to collaborate with international organizations to develop strategies minimizing the generation of microplastics; 2) to promote the development of regulatory instruments for the prevention, management and collection of marine residues; 3 ) to promote national research and innovation on marine residues and their impacts on the environment and finally 4) to promote the involvement of society in actions to prevent the generation of marine residues and its impacts on the environment.

\section{The Plastics Trojan Effect in Chile: Chemical Agents and Microbial Pathogens}

The real impact of ingested microplastics has not yet been determined (WHO, 2019). One potential harm is that microplastics can behave as vectors transporting organic pollutants including Persistent Organic Pollutants (POPs), chemical additives and heavy metals; which can be adsorbed onto the hydrophobic surface of plastics fragments i.e., microplastics (Pozo et al., 2020). Indeed, it has been demonstrated that marine microplastics (polyvinyl chloride, polyethylene, polypropylene, polystyrene) are able to adsorb a wide range of organic contaminants including polychlorinated biphenyls (PCBs), polycyclic aromatic hydrocarbons (PAHs), petroleum hydrocarbons, organochlorine pesticides (DDTs, $\mathrm{HCHs}$, polybrominated diphenyl ethers (PBDEs), alkylphenols and bisphenol A (BPA), at concentrations from sub ng/g to $\mu \mathrm{g} / \mathrm{g}$ (Mato et al., 2001; Rios et al., 2007; Teuten et al., 2009; Gómez et al., 2020; Pozo et al., 2020; Gómez et al., 2021; Ohgaki et al., 2021).

Plastics may also facilitate the transport of bacteria (Pham et al., 2021), which can form biofilms onto the microplastic's surface. Some biofilms may include bacterial pathogens such as Pseudomonas aeruginosa, Legionella spp, Mycobacterium spp (non-tuberculosis) and Naegleria fowleri (amoeba) (WHO, 2019). Most of these microorganisms have been related to human diseases and severe pathologies. A notorious example is the harmful algal bloom (HAB), which has been described to colonize marine macroplastics as well as microplastics (Casabianca et al., 2019). In Chile, the algae Alexandrium catanella has caused significant economic losses to the salmon industry, such as in 2009 when a large bloom was related with a loss of over $\$ 10$ million to the Chilean Salmon industry (Mardones et al., 2015). HAB species, potentially transported by microplastics, could therefore be incredibly damaging to global fishery and aquaculture industries.

Microplastics have also been reported as reservoirs of antibiotic-resistant bacteria in the recirculation of environmental systems (Zhang et al., 2020). Microplastics provide comparatively stable habitats for various microorganisms, facilitating their proliferation and biofilm formation. Zhang et al. (2020) analyzed a group of multiantibiotic resistant bacteria collected from microplastics recovered from mariculture systems, determining that resistant isolates were more frequent in the samples enriched with microplastics. Furthermore, Pham et al. (2021) demonstrated that microplastics present in wastewater treatment plants harbored both bacterial-biofilms and antibiotics, which can interact and promote the development of antibiotic resistant isolates. These data highlight the role of microplastics in antibiotic resistance, in which bacterial isolates are likely transported through wastewater into marine ecosystems (Bank et al., 2020). Surprisingly, to the best of our knowledge, there is no scientific literature regarding bacteria-microplastic interaction in Chilean environments.

\section{DISCUSSION}

Chile is a country with diverse environments and biota that borders the South Pacific Ocean. Given Chile's close relationship and reliance on the sea, it is critical to continue promoting research regarding the distribution and bioaccumulation of microplastics in Chilean waters. It is also important to start investigating the detrimental effects of the microplastics' interactions with contaminants and microbial communities. Unfortunately, there is a paucity of microplastic research in Chile. To date, there has not been a systematic study of microplastic occurrence, fate and distribution in either marine or terrestrial environments. Research on the bioaccumulation of microplastics in Chilean environments is also limited. Efforts have been made to study the bioaccumulation of microplastics in fish (Figure 1B) from Easter Island (D. muroadsi, C. rapanouiensis and T. albacares, Chagnon et al., 2018) and in intertidal fish from central Chile (G. laevifrons, S. viridis, G. nigra, $H$. chilensis and A. microcirrhis, Thiel et al., 2018). Microplastics have also been detected in commercial fish from central Chile including E. maclovinus, A. punctatus, B. australis, T. murphyi, $S$. bentincki and M. gayi (Pozo et al., 2019). Marine mammals in Chilean coasts have been particularly underexplored with only two reports showing the presence of microplastics in scat from American fur seals (A. australis) (Perez-Venegas et al., 2018, 2020).

Figure 2 summarizes the microplastic generation process as well as current knowledge and gaps concerning microplastic 


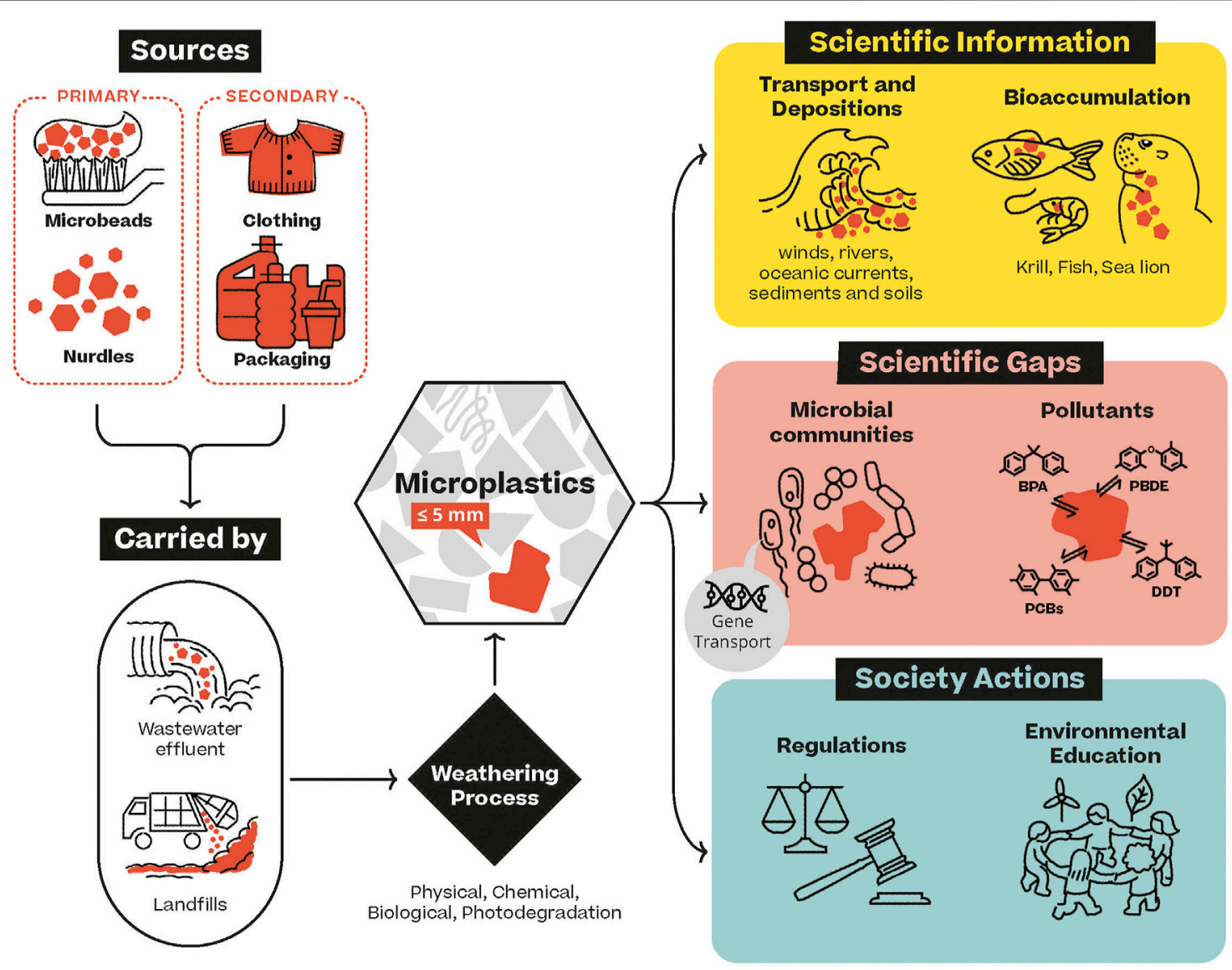

FIGURE 2| Overall sources and transport of microplastic, and the current exiting efforts in Chile about microplastic pollution including research, scientific gaps and society action.

pollution in Chile. Plastic waste accumulates in landfills and aquatic environments via wastewater effluents. A weathering process then induces fragmentation of the plastic waste, leading to the formation of microplastics. A large body of work has been devoted to studying the distribution and bioaccumulation of microplastics. However, there are major areas that remain poorly explored and that need to be addressed, including: 1) microplastic-microorganism association, 2) microplastic-gene transport, and 3) microplastic-organic pollutant interactions (Figure 2).

Fortunately, Chile's society actions on this topic are heading in a positive direction (Figure 2). Since 2015, Chile is officially committed to the UN's SDGs. As a consequence, in 2018, Chile was the first country in Latin America to eliminate single-use plastic bags from commerce. Also, the Chilean government has agreed to develop a National Strategy on marine litter together with an Action Plan, for the period 2021-2030. However, reaching these environmental goals will be a challenging task. According to the data obtained from the "International Beach Cleaning Day" in Chile, the largest amount of waste collected were pieces of plumage (45\%), cigarette butts (21\%), plastic bottle caps $(6.3 \%)$, food wrappers $(5.6 \%)$, plastic bags $(4.3 \%)$, pieces of plastic, pieces of glass, drink bottles, drink cans and glass bottles
(17.8\%) (Directemar, 2017). Considering this information, the education of the population will be a key factor in the reduction of pollution on the shared local places which are being constantly damaged by littering. Public policies will be necessary to reach these goals and the government will need the support of the public and private sectors.

It has been well established that microplastics can serve as vehicles to transport harmful chemicals and metals (referred to as the Trojan effect; Godoy et al., 2019; Hildebrandt et al., 2021). In Chile, reports have shown the ability of microplastics to adsorb contaminants including PCBs, PAHs, petroleum hydrocarbons, DDTs, HCHs, PBDEs, alkylphenols and BPA. However, there are no studies regarding metal adsorption in microplastics (Figure 2). This is an important line of research in Chile due to the strong metal industry in the north. The Trojan effect of microplastics have also been observed in bacteria and antibiotics. To date and to the best of our knowledge, there are no reported studies about the ability of microplastics to transport bacteria and antibiotics in Chile (Figure 2), where the use of antibiotics in salmon farming is excessive (AhumadaRudolph et al., 2021) and could potentially lead to the development of antibiotic resistance (Cabrera-Pardo et al., 2019). Thus, it is paramount to understand the dynamics of 
antibiotics transport by microplastics in Chile, especially in salmon farming areas. Recently, a potential link between microplastics and antibiotic-resistance was proposed. In this context, it has been demonstrated that microplastics are able to accumulate antibiotic-resistance genes (ARGs), which can mediate their dissemination through the environment (Liu et al., 2021). This phenomenon may be even more critical since bacterial biofilms are present on the surfaces of microplastics as reported by Pham et al. (2021). These processes could play an important role in the dissemination of antibiotic-resistant bacteria and ARGs (Bank et al., 2020), aggravating this crisis. Unfortunately, scientific reports on this line of research are, to this date, unexplored in Chile (Figure 2).

Chile needs to invest more scientific efforts to combat this environmental and human threat. Future endeavors should be focused on systematic study of the distribution of microplastics across the country as well as the association of toxic chemicals, metals and bacteria on their surfaces. This information will be crucial to determine the risk of Trojan effect of microplastics in Chilean environments. Special attention should be put on the adsorption of antibiotics and multi-resistant bacteria, both of which heavily contribute to the antibiotic resistance crisis. These studies would be particularly relevant in areas where antibiotic abuse is a constant threat (i.e. salmon farming industry, Miranda et al., 2018). Finally, as a country Chile needs increased education programs to create awareness of the problem of

\section{REFERENCES}

Ahumada-Rudolph, R., Novoa, V., Becerra, J., Cespedes, C., and Cabrera-Pardo, J. R. (2021). Mycoremediation of Oxytetracycline by Marine Fungi Mycelium Isolated From Salmon Farming Areas in the South of Chile. Food Chem. Toxicol. 152, 112198. doi:10.1016/j.fct.2021.112198

Ajith, N., Arumugam, S., Parthasarathy, S., Manupoori, S., and Janakiraman, S. (2020). Global Distribution of Microplastics and its Impact on Marine Environment-A Review. Environ. Sci. Pollut. Res. 27, 25970-25986. doi:10.1007/s11356-020-09015-5

Andrade, C., and Ovando, F. (2017). First Record of Microplastics in Stomach Content of the Southern King Crab Lithodes Santolla (Anomura: Lithodidae), Nassau bay, Cape Horn, Chile. Anales Instituto Patagonia (Chile). 45, 59-65. doi:10.4067/s0718-686x2017000300059

Bank, M. S., Ok, Y. S., and Swarzenski, P. W. (2020). Microplastic's Role in Antibiotic Resistance. Science. 369, 1315. doi:10.1126/science.abd9925

Bornscheuer, U. T. (2016). MICROBIOLOGY. Feeding on Plastic. Science. 351, 1154-1155. doi:10.1126/science.aaf2853

Boucher, J., and Friot, D. (2017). Primary Microplastics in the Oceans: A Global Evaluation of Sources Gland, Switzerland: IUCN, 43. doi:10.2305/ IUCN.CH.2017.01.en

Bravo, M., de los Ángeles Gallardo, M., Luna-Jorquera, G., Núñez, P., Vásquez, N., and Thiel, M. (2009). Anthropogenic Debris on Beaches in the SE Pacific (Chile): Results From a National Survey Supported by Volunteers. Mar. Pollut. Bull. 58, 1718-1726. doi:10.1016/j.marpolbul.2009.06.017

Cabrera-Pardo, J. R., Lood, R., Udekwu, K., Gonzalez-Rocha, G., Munita, J. M., Järhult, J. D., et al. (2019). A One Health - One World Initiative to Control Antibiotic Resistance: A Chile - Sweden Collaboration. One Health. 8, 100100. doi:10.1016/j.onehlt.2019.100100

Casabianca, S., Capellacci, S., Giacobbe, M. G., Dell'Aversano, C., Tartaglione, L., Varriale, F., et al. (2019). Plastic-Associated Harmful Microalgal Assemblages in Marine Environment. Environ. Pollut. 244, 617-626. doi:10.1016/ j.envpol.2018.09.110 microplastic pollution and to develop strategies that address it in the future.

\section{AUTHOR CONTRIBUTIONS}

$\mathrm{PB}$ and JC-P participate in the outline planning, the data collection, figures design, writing and editing. EP-O participated in the writing and editing. $\mathrm{AO}-\mathrm{C}$ and $\mathrm{KP}$ participated in the editing and review. All authors contributed to the article and approved the submitted version.

\section{ACKNOWLEDGMENTS}

We acknowledge Prof. Ellen Leffler for editorial feedback of this manuscript. JC-P acknowledges ANID Fondecyt Regular 1190652 and MEC 80190048. AO-C acknowledges ANID Fondecyt Iniciación 11190602. PB acknowledges ANID-Millennium Science Initiative-NCN16_034, and FONDECYT Iniciacion 11180914. KP acknowledges Fondecyt regular 1211931. KP also acknowledges the support from Research Infrastructure RECETOX RI (No LM2018121 and CZ.02.1.01/0.0/0.0/16_013/0001761) financed by the Ministry of Education, Youth and Sports, and Operational Programme Research, Development and Innovation-project CETOCOEN EXCELLENCE (No CZ.02.1.01/0.0/0.0/17_043/0009632).

Castillo, C., Fernández, C., Gutiérrez, M. H., Aranda, M., Urbina, M. A., Yáñez, J., et al. (2020). Water Column Circulation Drives Microplastic Distribution in the Martínez-Baker Channels; A Large Fjord Ecosystem in Chilean Patagonia. Mar. Pollut. Bull. 160, 111591. doi:10.1016/j.marpolbul.2020.111591

Chagnon, C., Thiel, M., Antunes, J., Ferreira, J. L., Sobral, P., and Ory, N. C. (2018). Plastic Ingestion and Trophic Transfer between Easter Island Flying Fish (Cheilopogon Rapanouiensis) and Yellowfin Tuna (Thunnus albacares) from Rapa Nui (Easter Island). Environ. Pollut. 243, 127-133. doi:10.1016/ j.envpol.2018.08.042

Corradini, F., Casado, F., Leiva, V., Huerta-Lwanga, E., and Geissen, V. (2021). Microplastics Occurrence and Frequency in Soils under Different Land Uses on a Regional Scale. Sci. Total Environ. 752, 141917. doi:10.1016/ j.scitotenv.2020.141917

Cox, K. D., Covernton, G. A., Davies, H. L., Dower, J. F., Juanes, F., and Dudas, S. E. (2019). Human Consumption of Microplastics. Environ. Sci. Technol. 53, 7068-7074. doi:10.1021/acs.est.9b01517

De Falco, F., Cocca, M., Avella, M., and Thompson, R. C. (2020). Microfiber Release to Water, via Laundering, and to Air, via Everyday Use: A Comparison Between Polyester Clothing With Differing Textile Parameters. Environ. Sci. Technol. 54, 3288-3296. doi:10.1021/acs.est.9b06892

Directemar (2017). Reporte Nacional Limpieza de Playas. Available at: https:// www.directemar.cl/directemar/intereses-maritimos/limpieza-de-playas.

Fadare, O. O., Wan, B., Guo, L.-H., and Zhao, L. (2020). Microplastics From Consumer Plastic Food Containers: Are We Consuming it? Chemosphere. 253, 126787. doi:10.1016/j.chemosphere.2020.126787

Fariña, J. M., Aldana, M., Ogalde, F., and Ojeda, F. P. (2000). Ecología trófica de Girella laevifrons (Pisces: Kyphosidae) en zonas intermareales rocosas del norte de Chile afectadas y no afectadas por contaminantes derivados de la minería del cobre. Rev. Chil. Hist. Nat. 73, 139. doi:10.4067/s0716-078x2000000100013

Geyer, R., Jambeck, J. R., and Law, K. L. (2017). Production, Use, and Fate of All Plastics Ever Made. Sci. Adv. 3, 3-8. doi:10.1126/sciadv.1700782

Godoy, V., Blázquez, G., Calero, M., Quesada, L., and Martín-Lara, M. A. (2019). The Potential of Microplastics as Carriers of Metals. Environ. Pollut. 255, 113363. doi:10.1016/j.envpol.2019.113363 
Gómez, V., Pozo, K., Nuñez, D., Přibylová, P., Audy, O., Baini, M., et al. (2020). Marine Plastic Debris in Central Chile: Characterization and Abundance of Macroplastics and Burden of Persistent Organic Pollutants (POPs). Mar. Pollut. Bull. 152, 110881. doi:10.1016/j.marpolbul.2019.110881

Gómez, V., Torres, M., Karásková, P., Přibylová, P., Klánová, J., and Pozo, K. (2021). Occurrence of Perfluoroalkyl Substances (PFASs) in marine Plastic Litter From Coastal Areas of Central Chile. Mar. Pollut. Bull. 172, 112818-112826. doi:10.1016/j.marpolbul.2021.112818

Gouin, T., Roche, N., Lohmann, R., and Hodges, G. (2011). A Thermodynamic Approach for Assessing the Environmental Exposure of Chemicals Absorbed to Microplastic. Environ. Sci. Technol. 45, 1466-1472. doi:10.1021/es1032025

Hartmann, N. B., Hüffer, T., Thompson, R. C., Hassellöv, M., Verschoor, A., Daugaard, A. E., et al. (2019). Are We Speaking the Same Language? Recommendations for a Definition and Categorization Framework for Plastic Debris. Environ. Sci. Technol. 53, 1039-1047. doi:10.1021/acs.est.8b05297

Hernandez, L. M., Xu, E. G., Larsson, H. C. E., Tahara, R., Maisuria, V. B., and Tufenkji, N. (2019). Plastic Teabags Release Billions of Microparticles and Nanoparticles Into tea. Environ. Sci. Technol. 53, 12300-12310. doi:10.1021/acs.est.9b02540

Hidalgo-Ruz, V., and Thiel, M. (2013). Distribution and Abundance of Small Plastic Debris on Beaches in the SE Pacific (Chile): A Study Supported by a Citizen Science Project. Mar. Environ. Res. 87, 12-18. doi:10.1016/j.marenvres.2013.02.015

Hildebrandt, L., Nack, F. L., Zimmermann, T., and Pröfrock, D. (2021). Microplastics as a Trojan Horse for Trace Metals. J. Hazard. Mater. Lett. 2, 100035. doi:10.1016/j.hazl.2021.100035

Karami, A., Golieskardi, A., Keong Choo, C., Larat, V., Galloway, T. S., and Salamatinia, B. (2017). The Presence of Microplastics in Commercial Salts From Different Countries. Sci. Rep. 7, 1-11. doi:10.1038/srep46173

Kutralam-Muniasamy, G., Pérez-Guevara, F., Elizalde-Martínez, I., and Shruti, V. C. (2020). Branded Milks - Are They Immune From Microplastics Contamination? Sci. Total Environ. 714, 136823. doi:10.1016/j.scitotenv.2020.136823

Law, K. L., and Thompson, R. C. (2014). Microplastics in the Seas. Science. 345, 144-145. doi:10.1126/science.1254065

Liebezeit, G., and Liebezeit, E. (2014). Synthetic Particles as Contaminants in German Beers. Food Additives \& Contaminants: A. 31, 1574-1578. doi:10.1080/ 19440049.2014.945099

Liu, Y., Liu, W., Yang, X., Wang, J., Lin, H., and Yang, Y. (2021). Microplastics Are a Hotspot for Antibiotic Resistance Genes: Progress and Perspective. Sci. Total Environ. 773, 145643. doi:10.1016/j.scitotenv.2021.145643

Mardones, J. I., Dorantes-Aranda, J. J., Nichols, P. D., and Hallegraeff, G. M. (2015). Fish Gill Damage by the Dinoflagellate Alexandrium Catenella From Chilean Fjords: Synergistic Action of ROS and PUFA. Harmful Algae. 49, 40-49. doi:10.1016/j.hal.2015.09.001

Mato, Y., Isobe, T., Takada, H., Kanehiro, H., Ohtake, C., and Kaminuma, T. (2001). Plastic Resin Pellets as a Transport Medium for Toxic Chemicals in the Marine Environment. Environ. Sci. Technol. 35, 318-324. doi:10.1021/es0010498

Miranda, C. D., Godoy, F. A., and Lee, M. R. (2018). Current Status of the Use of Antibiotics and the Antimicrobial Resistance in the Chilean Salmon Farms. Front. Microbiol. 9, 1-14. doi:10.3389/fmicb.2018.01284

Mizraji, R., Ahrendt, C., Perez-Venegas, D., Vargas, J., Pulgar, J., Aldana, M., et al. (2017). Is the Feeding Type Related With the Content of Microplastics in Intertidal Fish Gut? Mar. Pollut. Bull. 116, 498-500. doi:10.1016/j.marpolbul.2017.01.008

Ohgaki, T., Takada, H., Yoshida, R., Mizukawa, K., Yeo, B. G., Alidoust, M., et al. (2021). International Pellet Watch: Global Monitoring of Polybrominated Diphenyl Ethers (PBDEs) in Plastic Resin Pellets. Environ. Monit. Contam. Res. 1, 75-90. doi:10.5985/emcr.20210002

Ory, N. C., Sobral, P., Ferreira, J. L., and Thiel, M. (2017). Amberstripe Scad Decapterus Muroadsi (Carangidae) Fish Ingest Blue Microplastics Resembling Their Copepod Prey Along the Coast of Rapa Nui (Easter Island) in the South Pacific Subtropical Gyre. Sci. Total Environ. 586, 430-437. doi:10.1016/ j.scitotenv.2017.01.175

Perez-Venegas, D. J., Seguel, M., Pavés, H., Pulgar, J., Urbina, M., Ahrendt, C., et al. (2018). First Detection of Plastic Microfibers in a Wild Population of South American Fur Seals (Arctocephalus Australis) in the Chilean Northern Patagonia. Mar. Pollut. Bull. 136, 50-54. doi:10.1016/j.marpolbul.2018.08.065

Perez-Venegas, D. J., Toro-Valdivieso, C., Ayala, F., Brito, B., Iturra, L., Arriagada, M., et al. (2020). Monitoring the Occurrence of Microplastic Ingestion in Otariids Along the Peruvian and Chilean Coasts. Mar. Pollut. Bull. 153, 110966. doi:10.1016/j.marpolbul.2020.110966
Perez-Venegas, D., Pavés, H., Pulgar, J., Ahrendt, C., Seguel, M., and GalbánMalagón, C. J. (2017). Coastal Debris Survey in a Remote Island of the Chilean Northern Patagonia. Mar. Pollut. Bull. 125, 530-534. doi:10.1016/ j.marpolbul.2017.09.026

Pham, D. N., Clark, L., and Li, M. (2021). Microplastics as Hubs Enriching Antibiotic-Resistant Bacteria and Pathogens in Municipal Activated Sludge. J. Hazard. Mater. Lett. 2, 100014. doi:10.1016/j.hazl.2021.100014

Pozo, K., Gomez, V., Torres, M., Vera, L., Nuñez, D., Oyarzún, P., et al. (2019). Presence and Characterization of Microplastics in Fish of Commercial Importance From the Biobío Region in Central Chile. Mar. Pollut. Bull. 140, 315-319. doi:10.1016/j.marpolbul.2019.01.025

Pozo, K., Urbina, W., Gómez, V., Torres, M., Nuñez, D., Přibylová, P., et al. (2020). Persistent Organic Pollutants Sorbed in Plastic Resin Pellet - "Nurdles" from Coastal Areas of Central Chile. Mar. Pollut. Bull. 151, 110786. doi:10.1016/ j.marpolbul.2019.110786

Rios, L. M., Moore, C., and Jones, P. R. (2007). Persistent Organic Pollutants Carried by Synthetic Polymers in the Ocean Environment. Mar. Pollut. Bull. 54, 1230-1237. doi:10.1016/j.marpolbul.2007.03.022

Teuten, E. L., Saquing, J. M., Knappe, D. R. U., Barlaz, M. A., Jonsson, S., Björn, A., et al. (2009). Transport and Release of Chemicals From Plastics to the Environment and to Wildlife. Phil. Trans. R. Soc. B. 364, 2027-2045. doi:10.1098/rstb.2008.0284

Thiel, M., Luna-Jorquera, G., Álvarez-Varas, R., Gallardo, C., Hinojosa, I. A., Luna, N., et al. (2018). Impacts of Marine Plastic Pollution From continental Coasts to Subtropical Gyres-Fish, Seabirds, and Other Vertebrates in the SE Pacific. Front. Mar. Sci. 5, 1-16. doi:10.3389/fmars.2018.00238

Tziourrou, P., Kordella, S., Ardali, Y., Papatheodorou, G., and Karapanagioti, H. K. (2021). Microplastics Formation Based on Degradation Characteristics of Beached Plastic Bags. Mar. Pollut. Bull. 169, 112470. doi:10.1016/ j.marpolbul.2021.112470

Valdés-Pineda, R., Pizarro, R., García-Chevesich, P., Valdés, J. B., Olivares, C., Vera, M., et al. (2014). Water Governance in Chile: Availability, Management and Climate Change. J. Hydrol. 519, 2538-2567. doi:10.1016/ j.jhydrol.2014.04.016

UNEP (2012) Marine Plastic Debris and Microplastics. doi:10.18356/0b228f55-en Wang, W., Gao, H., Jin, S., Li, R., and Na, G. (2019). The Ecotoxicological Effects of Microplastics on Aquatic Food Web, From Primary Producer to Human: A Review. Ecotoxicology Environ. Saf. 173, 110-117. doi:10.1016/j.ecoenv.2019.01.113

WHO (2017). WHO Guidelines on Use of Medically Important Antimicrobials in Food-Producing Animals. Available at: https://apps.who.int/iris/ bitstream/handle/10665/258970/9789241550130-eng.pdf? sequence $=1 \%$ 0Ahttp://apps.who.int/iris/bitstream/handle/10665/258970/ 9789241550130-eng.pdf? sequence $=1$.

WHO (2019). Microplastics in Drinking-Water. Genova, Switzerland: World Health Organization, 124. Available at: https://apps.who.int/iris/bitstream/ handle/10665/326499/9789241516198-eng.pdf?ua=1.

Zhang, Y., Lu, J., Wu, J., Wang, J., and Luo, Y. (2020). Potential Risks of Microplastics Combined With Superbugs: Enrichment of Antibiotic Resistant Bacteria on the Surface of Microplastics in Mariculture System. Ecotoxicology Environ. Saf. 187, 109852. doi:10.1016/j.ecoenv.2019.109852

Conflict of Interest: The authors declare that the research was conducted in the absence of any commercial or financial relationships that could be construed as a potential conflict of interest.

Publisher's Note: All claims expressed in this article are solely those of the authors and do not necessarily represent those of their affiliated organizations, or those of the publisher, the editors and the reviewers. Any product that may be evaluated in this article, or claim that may be made by its manufacturer, is not guaranteed or endorsed by the publisher.

Copyright (C) 2021 Paredes-Osses, Pozo, Opazo-Capurro, Bahamonde and CabreraPardo. This is an open-access article distributed under the terms of the Creative Commons Attribution License (CC BY). The use, distribution or reproduction in other forums is permitted, provided the original author(s) and the copyright owner(s) are credited and that the original publication in this journal is cited, in accordance with accepted academic practice. No use, distribution or reproduction is permitted which does not comply with these terms. 